2.6 times higher, in anterior ischemic DON - 2.7 times higher, in dystrophic stage -3.1 times higher than that of the control group $(303 \pm 56 \mu \mathrm{m})(\mathrm{p}<0,001)$.

Conclusions. As a result of the study a thickening of scleral lamina cribrosa in average 1.9 times greater as compared to healthy persons of an appropriate age was found. In $78.9 \%$ of eyes of the patients with DM a mild thickening of scleral lamina cribrosa $(<700 \mu \mathrm{m})$ was observed; in $16.6 \%$ of eyes a moderate thickening $(700-900 \mu \mathrm{m})$, and in $3.8 \%$ of eyes - a significant thickening $(<900 \mu \mathrm{m})$ was observed. The scientific data about the mechanisms of diabetic optic neuropathy were amplified. A thickening of scleral lamina cribrosa was found to play an essential role in the pathogenesis of diabetic optic neuropathy.

Key words: diabetic optic neuropathy, scleral lamina cribrosa, diabetes mellitus, scleral canal.

Стаття надійшла до редакції 09.03.2018 p.

І. В. Галінська

Вінницький національний медичний університет імені М. І. Пирогова

МОЗ України

- м. Вінниця, Україна

\title{
РОЗПОВСЮДЖЕНІСТЬ ТА ЕТІОЛОГІЯ ЧАСТКОВОÏ АТРОФІЇ ЗОРОВОГО НЕРВА
}

\begin{abstract}
Атрофія зорових нервів - важка поліетіологічна офтальмопатія, яка є одним із основних етіопатогенетичних чинників сліпоти, слабобачення та причин інвалідизації по зору.

Метою дослідження було проведення аналізу розповсюдженості та етіологічних факторів часткової атрофії зорового нерва (ЧАЗН). Був проведений ретроспективний аналіз 74 історій хвороб пацієнтів (137 очей) на ЧАЗН за період 2012-2016 pр. Встановлено, що вражається населення працездатного віку (середній вік $50,0 \pm 2,5$ року), і це підкреслює соціальну значимість даної проблеми. Переважно двобічна локалізація патологічного процесу (у 86 \% хворих) збільшує ризик інвалідизації внаслідок даної патології. У жінок ЧАЗН частіше має характер судинного генезу (52,9 \% випадків), а у чоловіків - запальної етіології (43,5 \% випадків).
\end{abstract}

Ключові слова: зоровий нерв, атрофія зорового нерва, розповсюдженість атрофії зорових нервів, етіологія.

Атрофія зорових нервів (АЗН) - важка поліетіологічна офтальмопатія, до розвитку якої призводять загальні захворювання (75,8 \%), вроджена патологія (18 \%) та травми (3-6,2\%). Захворювання є одним iз основних етіопатогенетичних чинників сліпоти, слабобачення (недобачання) та інвалідизації по зору [7-11].

За даними статистики в Україні за 7 років, частота АЗН як основної тяжкої нозологічної форми офтальмопатології у первинних інвалідів по зору склала в: 2011 році - 7,9\%, $2012-8,1 \%, 2013-7,9 \%, 2014$ $-8,9 \%, 2015-8,5 \%$. У 2016 році інтенсивний показник АЗН на 10 тис. дорослого населення склав 0,16. Серед первинних інвалідів 3 дитинства іiі частота склала 7,7 \% [1-6].
Серед етіологічних чинників АЗН переважають захворювання ЦНС: об'ємні процеси головного мозку (запалення мозку та його оболонок, пухлини, черепно-мозкові травми, порушення центрального кровообігу, абсцеси, гематоми, аневризми, туберкуломи, паразитарні кісти та кісти після геморагічного інсульту, спадкові ураження), нейроінфекції (менінгіти, енцефаліти, базальні арахноїдіти, розсіяний склероз), ішемічна хвороба серця, гіпертонічна хвороба, цукровий діабет, атеросклероз. За даними окремих авторів, чинниками ризику АЗН стали ішемічна хвороба серця $(23,43 \%)$, гіпертонічна хвороба $(20,56 \%)$, атеросклероз (18,6\%) [12-14].

За даними літератури, все більшого значення набувають токсичні та токсико-алергічні ураження зо- 
рового нерва, що зумовлено неконтрольованим прийомом суттєво розширеного арсеналу лікарських засобів, а також широкомасштабним впровадженням на виробництві хімічних нейротоксичних препаратів, зловживанням спиртними напоями та тютюнокурінням $[15,16]$.

Серед етіологічних чинників АЗН певне значення мають захворювання очного яблука. Це - ураження сітківки судинного генезу, патологія судин сітківки (запальні та алергічні васкуліти, непрохідність ЦАС та ЦВС), дистрофічні захворювання сітківки (в тому числі й пігментна дистрофія сітківки), ускладнення увеїтів (папіліт, хоріоретиніт), відшарування сітківки, первинна та вторинна глаукоми (запальна, факогенна, судинна, травматична, дистрофічна, неопластична). Тривала гіпотензія очного яблука після операцій, запальних дегенеративних захворювань циліарного тіла, проникаючих поранень очного яблука з утворенням фістули призводять до набряку ДЗН, після якого розвивається АЗН. Зоровий нерв уражається при невритах (папілітах), ретробульбарних невритах, пухлинах, травмах та захворюваннях орбіти (ретробульбарна гематома) [17].

Мета дослідження - проведення аналізу розповсюдженості та етіологічних факторів часткової атрофіï зорового нерва (ЧАЗН).

Матеріали і методи. 3 метою отримання сучасного уявлення про частоту захворювання та етіологію часткової атрофії зорового нерва, а також клінічну ефективність методів лікування даної патології опрацьовано 74 історії хвороби пацієнтів з діагнозом часткової атрофії зорового нерва, котрі перебували на лікуванні в очному відділенні Центральної міської лікарні № 1 м. Житомира у 2012-2016 роках.

Результати та їх обговорення. У табл. 1 наведено частоту захворювання на АЗН за даними очного відділення ЦМЛ м. Житомира у 2012-2016 роках.

Як видно із табл. 1, за період 2012-2016 рр. на стаціонарному лікуванні очного відділення ЦМЛ № 1 м. Житомира знаходилось 74 (137 очей) пацієнта 3 основним діагнозом: часткова атрофія зорового нерва. Частота АЗН в середньому склала 2,06 \%.

У табл. 2 наведено характеристику розподілу хворих на часткову АЗН.

Як видно із табл. 2, результати ретроспективного аналізу свідчать, що по розподілу хворих за ознакою одно- або двобічності ураження зорового нерва у 86 \% пацієнтів патологічний процес мав двобічну локалізацію, а це значно підсилює ризик інвалідизації внаслідок втрати функції органа зору.

Середній вік хворих становив $50,0 \pm 2,5$ року, причому молодша вікова група складалася з осіб чоловічої статі - середній показник був $44,7 \pm 3,5$ року, а у жінок - 55,6 $\pm 3,3$ року.

При аналізі соціального статусу хворих, госпіталізованих з приводу часткової АЗН у 2012-2016 рр., звертає на себе увагу високий відсоток пенсіонерів 57,8 \%, причому жінок у цій соціальній категорії вдвічі більше, ніж чоловіків.

Аналіз етіологічних факторів часткової АЗН встановив, що у чоловіків найчастіше спостерігався неврит зорового нерва (інтра- або ретробульбарний) (43,5 \%) та черепно-мозкова травма (22,5 \%), тоді як у жінок причинними факторами в першу чергу були ішеміч-

Таблиияя 1

Частота захворювання на АЗН за даними очного відділення ЦМЛ м. Житомира у 2012-2016 рр. (абсолютні величини)

\begin{tabular}{|c|c|c|c|c|c|c|}
\hline Рік & 2012 & 2013 & 2014 & 2015 & 2016 & $2012-2016$ \\
\hline Разом госпіталізовано & 706 & 644 & 733 & 777 & 736 & 3596 \\
\hline В тому числі з ЧАЗН & 17 & 10 & 16 & 16 & 15 & 74 \\
\hline
\end{tabular}

Характеристика розподілу хворих на часткову АЗН

\begin{tabular}{|c|c|c|c|c|}
\hline \multirow{2}{*}{ Рік } & Локалізація & Чоловіки, $\%$ & Жінки, $\%$ & Разом, $\%$ \\
\hline \multirow{2}{*}{2012} & Однобічна АЗН & 36,4 & 0 & 23,5 \\
\cline { 2 - 5 } & Двобічна АЗН & 63,6 & 100 & 76,5 \\
\hline \multirow{2}{*}{2013} & Однобічна АЗН & 33,3 & 0 & 20 \\
\cline { 2 - 5 } & Двобічна АЗН & 66,7 & 0 & 80 \\
\hline \multirow{2}{*}{2014} & Однобічна АЗН & 37,5 & 100 & 81,25 \\
\cline { 2 - 5 } & Двобічна АЗН & 62,5 & 14,3 & 12,5 \\
\hline \multirow{2}{*}{2015} & Однобічна АЗН & 11,1 & 85,7 & 87,5 \\
\cline { 2 - 5 } & Двобічна АЗН & 88,9 & 12,5 & 20 \\
\hline
\end{tabular}


на нейрооптикопатія (31,5 \%) та гіпертонічна хвороба $(21,4$ \%). У хворих з атрофією зорового нерва серед супутньої очної патології у осіб обох статей переважали катаракта і дистрофічні захворювання сітківки.

Клінічні дані історій хвороб пацієнтів свідчать, що, крім характерної офтальмоскопічної картини атрофії зорового нерва, спостерігалося значне зниження гостроти зору та звуження сумарного поля зору з наявністю абсолютних скотом в центральному полі зору.

Аналіз характеристики атрофії зорового нерва за ступенем тяжкості патологічного процесу нами не був проведений, оскільки при формулюванні діагнозу в історіях хвороб ступінь атрофії не зазначався.

За таких результатів лікування закономірно виникає питання про ефективність лікарської допомоги хворим. Однак згаданий аналіз лікування показав, що застосована тактика терапії відповідає протоколам надання медичної допомоги хворим на атрофію зорового нерва.

\section{Висновки}

Таким чином, проведений ретроспективний аналіз історій хвороб пацієнтів із частковою атрофією зорового нерва дає можливість зробити такі висновки:

1. Частота ЧАЗН за період з 2012-2016 рр. склала $2,06 \%$

2. Вражається населення працездатного віку (се-

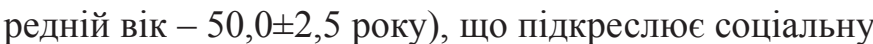
значимість даної проблеми.

3. Переважно двобічна локалізація патологічного процесу (у 86 \% хворих) збільшує ризик інвалідизації внаслідок даної патології.

4. У жінок часткова АЗН частіше має характер судинного генезу (52,9 \% випадків), а у чоловіків - запальної етіології (43,5 \% випадків).

\section{Література}

1. Inатов A. B. Основні показники інвалідності та діяльності медико-соціальних експертних комісій України за 2014 рік: аналітико-інформаційний довідник / А. В. Іпатов, О. М. Мороз, В. А. Голик та ін.; за ред. С. І. Черняка. - Дніпропетровськ: Роял-Принт, 2015. - 167 с.

2. Іпатов $A$. B. Основні показники інвалідності та діяльності медико-соціальних експертних комісій України за 2015 рік: аналітико-інформаційний довідник / А. В. Іпатов, О. М. Мороз, В. А. Голик та ін.; за ред. С. І. Черняка. - Дніпропетровськ: Акцент ПП, 2016. - 162 с.

3. Марунич В. В. Основні показники інвалідності та діяльності медико-соціальних експертних комісій України за 2011 р.: аналітико-інформаційний довідник / В. В. Марунич, А. В. Іпатов, Ю. І. Коробкін та ін.; за ред. Р. В. Богатирьової. - Д.: Пороги, 2012. - 150 с.
4. Черняк С. I. Основні показники інвалідності та діяльності медико-соціальних експертних комісій України за 2012 рік: аналітико-інформаційний довідник / C. І. Черняк, А. В. Іпатов, О. М. Мороз та ін.; за ред. М. К. Хобзея. - Дніпропетровськ: Пороги, $2012-150$ с.

5. Іпатов A. B. Основні показники інвалідності та діяльності медико-соціальних експертних комісій України за 2013 рік: аналітико-інформаційний довідник // А. В. Іпатов, С. І. Черняк, О. М. Мороз, та ін. - Дніпропетровськ: Роял Принт, 2014. $-176 \mathrm{c}$

6. Inатов A. B. Основні показники інвалідності та діяльності медико-соціальних експертних комісій України за 2015 рік: аналітико-інформаційний довідник / А. В. Іпатов, О. М. Мороз, В. А. Голик та ін.; за ред. С. І. Черняка. - Дніпропетровськ: Акцент ПП, 2016. - 162 с.

7. Васюта B. A. Експертна оцінка трирівневої системи профілактики атрофії зорових нервів / В. А. Васюта // Галицький лікарський вісник. - 2015. Т. 22, № 2. - C. 144-146.

8. Офтальмология: национальное руководство / под ред. С. Э. Аветисова, Е. А. Егорова, Л. К. Мошетовой [и др.] - М.: ГЭОТАР-Медиа, 2013. - 943 с.

9. Офтальмология: учебник / [Г. Д. Жабоедов, Р. Л. Скрипник, Т. В. Баран и др.]; - К. : ВСИ “Медицина", 2011. - 448 с.

10. Tan J. Ch. H. A pilot trial of tele-ophthalmology for diagnosis of chronic blurred vision / J. Ch. H. Tan, E. W. T. Poh, S. Srinivasan, T. H. Lim// J. Telemedicine and Telecare. - 2013. - Vol. 19. - P. 65-69.

11. Chinta S. Etiology and clinical profile of childhood optic nerve atrophy at a tertiary eye care center in South India / S. Chinta, B. S. Wallang, V. Sachdeva [et al.] // Indian J. Ophthalmol. - 2014. - Vol. 62, N 10. - P. 1003-1007.

12. Скрипник Р. Л. Пошкодження зорового нерва при цукровому діабеті (патогенез, клініка, діагностика, лікування) : автореф. дис. на здобуття наук. ступеня д-ра мед. наук : спец. 14.01.18 “Офтальмологія” / Р. Л. Скрипник. - Київ, 2005. - 45 с.

13. Giacalone J. C. Eye disease / J. C. Giacalone, L. A. Wiley, E. R. Burnight [et al.] // Stem Cells Trans. Med. - 2016. - Vol. 5. - P. 132-140.

14. Newman N. J. Treatment of Leber hereditary optic neuropathy / N. J. Newman // Brain. - 2011. - Vol. 134. - P. 2447-2450.

15. Grzybowski A. Toxic optic neuropathies: an updated review / A. Grzybowski, M. Zülsdorff, H. Wilhelm, F. Tonagel // Acta Ophthalmol. - 2015. - Vol. 93, N 5. - P. 402-410.

16. Trelohan $A$. Reversible optic neuropathy related to disulfiram / A. Trelohan, D. Milea // J. Fr. Ophtalmol. - 2011. - Vol. 34, N 6. - P. 382, e1-3. 
17. Ohle R. Sonography of the optic nerve sheath diameter for detection of raised intracranial pressure compared to Computed Tomography: A systematic review and meta- analysis / R. Ohle, S. M. McIsaac, M. Y. Woo, J. J. Perry

// J. Ultrasound Med. - 2015. - Vol. 34. - P. 1285-1294.

\title{
РАСПРОСТРАНЕННОСТЬ И ЭТИОЛОГИЯ ЧАСТИЧНОЙ АТРОФИИ ЗРИТЕЛЬНОГО НЕРВА
}

\author{
И. В. Галинская
}

Атрофия зрительных нервов - тяжелая полиэтиологическая офтальмопатия, которая является одним из основных этиопатогенетических факторов слепоты, слабовидения и причин инвалидности по зрению. Целью исследования было проведение анализа распространенности и этиологических факторов частичной атрофии зрительного нерва (ЧАЗН). Был проведен ретроспективный анализ 74 историй болезни пациентов (137 глаз) на ЧАЗН за период 2012-2016 гг. Установлено, что поражается население трудоспособного возраста (средний возраст - 50,0 2,5 года), и это подчеркивает социальную значимость данной проблемы. Преимущественно двухсторонняя локализация патологического процесса (у 86 \% больных) увеличивает риск инвалидизации в результате данной патологии. У женщин ЧАЗН носит характер чаще сосудистой этиологии (52,9\% случаев), а у мужчин - воспалительного генеза (43,5 \% случаев).

Ключевые слова: зрительный нерв, атрофия зрительного нерва, распространенность атрофии зрительных нервов, этиология.

\section{DISTRIBUTION AND ETIOLOGY OF PARTIAL OPTIC NERVE ATROPHY}

\author{
I. V. Galinska \\ Vinnytsa National Medical University named after M. I. Pirogov \\ Vinnitsa, Ukraine, \\ "Regional Clinical Hospital named after O. F. Gerbachevsky" Zhytomyr Oblast Council \\ Zhytomyr, Ukraine
}

Introduction. Atrophy of the optic nerves (AON) is a severe polyethiologic ophthalmopathy, the development of which is led by common diseases $(75,8 \%)$, congenital pathology (18\%) and injuries (3-6,2\%). The disease is one of the main etiopathogenetic factors of blindness, weak vision and visual disability. According to the statistics data of Ukraine for 7 years, the frequency of AON as the main severe nosological form of ophthalmopathology in primary visual disability was 7,9\% in 2011, 8,1\% in 2012, 7,9\% in 2013, 2014 in 8,9\% and 2015 in 8,5\%. In 2016, an intensive indicator of AON for ten thousand adults was 0,16 .

Among the etiological factors of the AON the diseases of the central nervous system prevail, neuroinfections (meningitis, encephalitis, basal arachnoiditis, multiple sclerosis), ischemic heart disease, hypertension, diabetes mellitus, atherosclerosis. According to literature, toxic and toxic-allergic lesions of the optic nerve become more and more important due to the wide-scale production of chemical neurotoxic drugs, abuse of alcoholic beverages and tobacco smoke.

Also among the etiologic factors of AON, illnesses of the eyeball is of a particular importance. This is a lesions of the retina vascular etiology, the pathology of the retina vessels (inflammatory and allergic vasculitis, obstruction of the central artery of the retina and central vien of the retina, degenerative diseases of the retina). In addition, the optic nerve is affected by neuritis (papillitis), retrobulbar neuritis, tumors, traumas and diseases of the orbit.

Aim of the study. Make an analysis of the distribution and etiological factors of partial atrophy of the optic nerve (PAON).

Material and methods. In order to obtain a modern view on the frequency of the disease and the etiology of partial atrophy of the optic nerve, and on the clinical efficacy of the treatment methods of this pathology, 74 histories of the disease in patients with a diagnosis of partial atrophy of the optic nerve treated at the eye department of the Central City Hospital No.1 in Zhytomyr in 2012-2016 years has been studied.

Results and discussion. For the period of 2012-2016, there were 74 (137 eyes) patients with the main diagnosis of partial atrophy of the optic nerve in the eye department of the Central City Hospital No.1 in Zhytomyr. The frequency of PAON was $2.06 \%$ on average. The results of the retrospective analysis indicate that in the distribution of patients on the basis of one- or two-sided lesions of the optic nerve, in $86 \%$ of patients the pathological process had a bilateral localization. The average age of patients was $(50,0 \pm 2,5)$ years. In the analysis of the social status of patients hospitalized for PAON in 2012-2016, the high percentage are pensioners (57,8 \%), and women in this social category are twice as many as men. The analysis of the etiological factors of the PAON found that the neuritis of the optic nerve (intra- or 
retrobulbar) was in men $(43,5 \%)$ as wel as craniocerebral trauma $(22,5 \%)$, whereas in women the causative factors were primarily ischemic neuroopticopathy $(31.5 \%)$ and hypertonic disease $(21,4 \%)$.

Clinical data from patients' disease histories show that in addition to the characteristic ophthalmoscopic pattern of optic nerve atrophy, there was a significant reduction in visual acuity and narrowing of the total field of view with the presence of absolute scotoms in the central field of view.

The results of the treatment naturally raise the question of the effectiveness of medical care for patients. However, the analysis of the treatment of patients showed that the applied treatment tactics is consistent with medical aid protocols for patients with atrophy of the optic nerve.

Conclusions. Thus, a retrospective analysis of the patient's disease history of partial atrophy of the optic nerve allows us to draw the following conclusions: 1. Frequency PAON for the period of 2012-2016 amounted to 2,06 \%. 2. PAON affects population of working age (average age 50,0土2,5 years), that emphasizes the social significance of this problem. 3. Prevalently bilateral localization of the pathological process (in $86 \%$ of patients) increases the risk of disability due to this pathology. 4 . In women, partial AON is more common in vascular genesis (52,9\% of cases), and in men - inflammatory etiology ( $43,5 \%$ of cases).

Key words: optic nerve, optic nerve atrophy, distribution of optic nerve atrophy, etiology.

Стаття надійшла до редакції 29.03.2018 р.

А. С. Гудзь, Г. Є. Захаревич, О. В. Петренко, Г. Г. Луньова

Львівський національний медичний університет імені Данила Галицького МОЗ України

- м. Львів, Україна

\section{ПРОГНОЗУВАННЯ РОЗВИТКУ ТА ПРОГРЕСУВАННЯ ДІАБЕТИЧНОЇ РЕТИНОПАТІЇ ПРИ ЦУКРОВОМУ ДІАБЕТІ 2-ГО ТИПУ}

Метою дослідження було прогнозування розвитку та прогресування діабетичної ретинопатії (ДР) при цукровому діабеті 2-го типу (ЦД2Т) на підставі побудови і аналізу регресійних логістичних моделей з визначенням ймовірності розвитку ДР, а також швидкості ії прогресування. Залучено 302 особи: 1-а група ( $\mathrm{n}=76)$ - пацієнти з ДР без змін на очному дні; 2-a $(\mathrm{n}=64)$ - пацієнти 3 непроліферативною і 3-я $(\mathrm{n}=64)$ - 3 проліферативною ДР (ДПР). Контрольну групу склали 98 пацієнтів без цукрового діабету. При побудові логістичної регресії були враховані стать, вік, тривалість захворювання на діабет і результати генотипування поліморфізмів rs2010963 i rs699947 гена VEGFA. Аналіз ДНК-локусів здійснювали з використанням TaqMan Mutation Detection Assays Thermo Fisher Scientific (США) в автоматичному ампліфікаторі Real-Time PCR System 7500 (Applied Biosystems, США). Розраховані $\beta$-коефіцієнти математичної моделі розрахунку ймовірності розвитку ДР та ДПР для показників: “Тривалість захворювання на діабет”, “Стать” та “"rs2010963” вказували на наявність прямого, а для показників: “Вік” і “rs699947” - зворотного зв'язку з результуючою змінною. Модель розрахунку ймовірності розвитку ДР мала показник максимальної правдоподібності $(-2 * \log )=254,44$ при $\chi^{2}=157,2(\mathrm{p}<0,001)$ та високу прогностичну характеристику: область під кривою $(\mathrm{AUC})=0,90 \pm 0,02 ; 95 \% \mathrm{BI}=0,87-0,93 ; \mathrm{p}=1,24 \mathrm{E}-04$. Модель розрахунку ймовірності розвитку ДПР мала показник максимальної правдоподібності $(-2 * \log )=285,2$ при $\chi^{2}=168,04$ $(\mathrm{p}<0,001)$ та високу прогностичну характеристику: область під кривою (AUC) $=0,86 \pm 0,03$; $95 \% \mathrm{BI}=0,81-0,91 ; \mathrm{p}=2,15 \mathrm{E}-05$. Показана залежність прогресування ДР від генотипів rs2010963 i rs699947: представлені характеристики моделі демонстрували іï високу прогностичну здатність щодо залежного показника: $\mathrm{R}=0,714 ; \mathrm{R}^{2}=0,514 ; \mathrm{F}=93,9(\mathrm{p}<0,001)$.

Ключові слова: иукровий діабет 2-го типу, діабетична ретинопатія, ген VEGF, rs2010963, rs699947. 